\title{
Canine cutaneous leishmaniasis by Leishmania (Viannia) braziliensis in an agricultural settlement, endemic area for leishmaniasis
}

\author{
[Leishmaniose tegumentar canina por Leishmania (Viannia) braziliensis em um assentamento \\ agrícola, área endêmica para leishmanioses] \\ A.F. Brilhante ${ }^{1}$, A.I. Souza ${ }^{2}$, M.E.C. Dorval ${ }^{2}$, A.O. França ${ }^{2}$, R.B. Lima ${ }^{3}$, \\ E.A.B. Galati ${ }^{1}$, V.L.B. Nunes ${ }^{4}$ \\ ${ }^{1}$ Faculdade de Saúde Pública - Universidade de São Paulo - São Paulo, SP \\ ${ }^{2}$ Universidade Federal de Mato Grosso do Sul - Campo Grande, MS \\ ${ }^{3}$ Fundação Oswaldo Cruz - Rio de Janeiro, RJ \\ ${ }^{4}$ Universidade Anhanguera - UNIDERP - Campo Grande, MS
}

\begin{abstract}
Cutaneous leishmaniasis has several species of Leishmania as agents, and a wide variety of wild and domestic animals as hosts and different species of phlebotomines as vectors. A case of cutaneous leishmaniasis in a dog coming from an agricultural settlement is described. This is the first report of parasitism in a dog by Le. (Viannia) braziliensis in Mato Grosso do Sul State. Attention is called to the importance of including this protozoonosis in the differential diagnosis of dermopathies in dogs as also the need to assess the importance of the domestic dog as a possible reservoir of Le. braziliensis.
\end{abstract}

Keywords: domestic dog, human cases, reservoir

\section{RESUMO}

As leishmanioses tegumentares são antropozoonoses metaxênicas de importância em saúde pública. Possuem como agentes etiológicos várias espécies de Leishmania, com ampla variedade de hospedeiros, como animais selvagens e domésticos, e diferentes espécies de flebotomíneos como vetores. Um caso de leishmaniose tegumentar em um cão procedente de um assentamento agrícola em Mato Grosso do Sul é descrito, sendo este o primeiro relato de parasitismo em cão doméstico nesse estado por Le. (Viannia) braziliensis. Alerta-se para a importância de se incluir essa protozoonose no diagnóstico diferencial de dermopatias em cães e para a necessidade de se avaliar o papel do cão doméstico como reservatório de Le. (Vi.) braziliensis.

Palavras-chave: cão doméstico, casos humanos, reservatório

\section{INTRODUCTION}

In Brazil ACL is a disease with a diversity of agents, reservoirs and vectors which presents various patterns of transmission, though knowledge as to its epidemiological structure is limited (Lainson and Shaw, 2005).

A case of canine cutaneous leishmaniasis (CCL) attributed to Leishmania (Viannia) braziliensis in a dog from an agricultural settlement in the municipality of Bonito, Mato Grosso do Sul
State, a region endemic for leishmaniasis, is here described and its role as a possible reservoir is discussed in light of prior information on the occurrence of human cases and natural infection by Leishmania (Viannia) sp. in phlebotomines in this settlement.

\section{CASUISTIC}

A female adult canine from an agricultural settlement situated in the central part of the Serra da Bodoquena $\left(20^{\circ} 27^{\prime} 40.926^{\prime \prime} \mathrm{S}\right.$ and $56^{\circ} 52^{\prime}$ 4.987" W), in the municipality of Bonito, Mato

Recebido em 16 de novembro de 2015

Aceito em 18 de fevereiro de 2016

E-mail: brilhanteaf@usp.br 
Grosso do Sul, was delivered in August 2008 by its owner to the University Hospital of the Agrarian Units of the Universidade Anhanguera/Uniderp for examination in view of the presence of skin lesions in the head region.

For the research into the amastigote forms, slides were prepared with fragments of the lesions and with bone marrow aspirate, fixed in methyl alcohol and colored by the Giemsa method. For the isolation of the parasite, sowing in a biphasic NNN (Neal, Novy, Nicolle) medium, containing BHI (Brain Heart Infusion) as liquid phase, was undertaken. Previously the material had been immersed in saline solution with gentamicin sulfate for 24 hours at $4^{0} \mathrm{C}$. The cultures were maintained at $25^{\circ} \mathrm{C}$ and examined weekly.

Clinical assessment revealed a circumscribed, ulcerous lesion of approximately $1.5 \mathrm{~cm}$ diameter in the mucocutaneous region of the right nostril (Fig. 1) and three others, one ulcerated and two crusted, of different sizes, on the head. No wasting or evidence of systemic disease was observed.
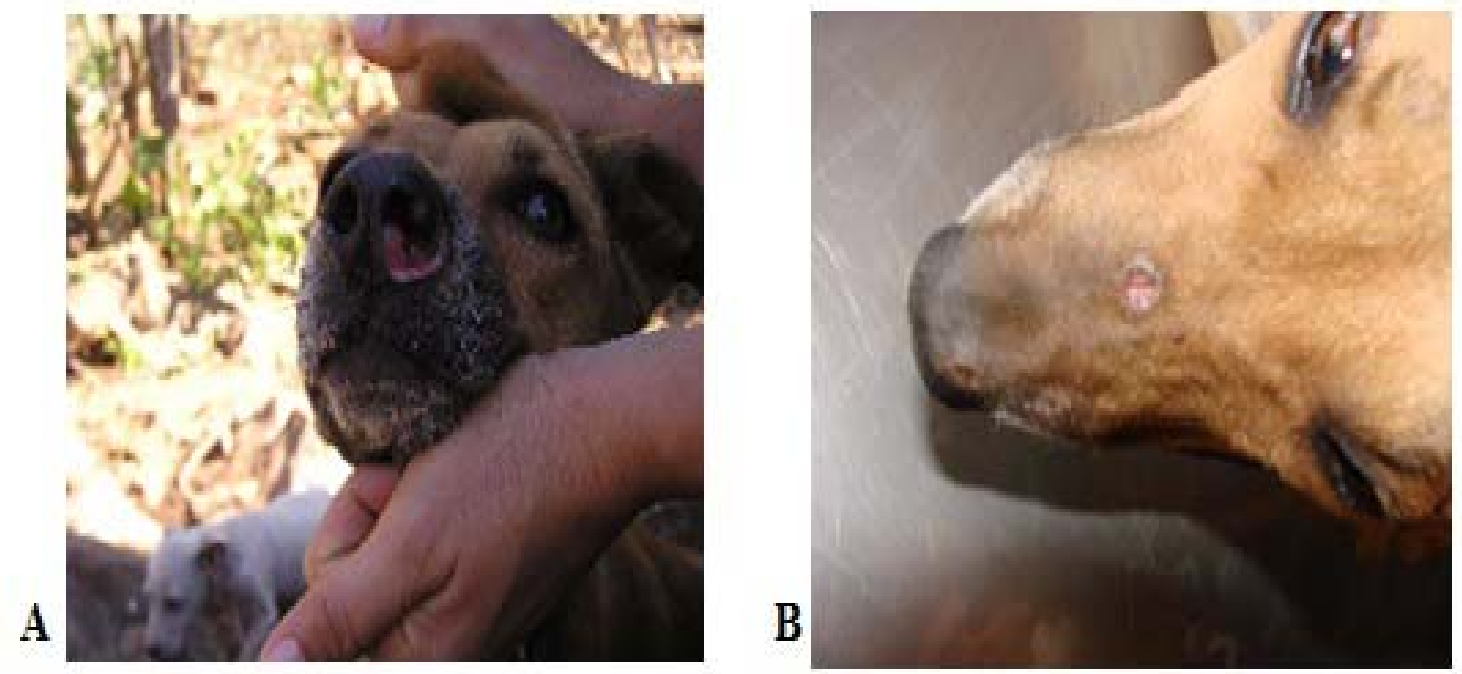

Figure 1 Skin lesions in a dog from an agricultural settlement of Bonito, MS, Brazil. A: ulcerative lesion in the ventral mucocutaneous region at the right nostril; B: lesions on the head.

The results of the routine hematological assessment and biochemical serum tests of urea, creatinine, aminotransferase alanine (ATL), albumin and total proteins (TP), were within the normal limits for the species.

Some rare amastigotes and promastigotes were observed on the slides eight days after the sowing of the material. The slides and the cultures of bone marrow aspirate were negative in the search for Leishmania.

For the isolation of DNA, the Illustra blood genomic Prep Mini Spin Kit (GE Healthcare) was used, according to the manufacturer's instructions. The target DNA for amplification of the polymerase chain reaction (PCR) was the conserved region of the molecule of the minicircle (kinetoplastid mitochondrial DNA; kDNA) with the primers HM1 [5'-(CCG CCC CTA TTT TAC ACC AAC CCC)-3], HM2 [5'(GGG GAG GGG CGT TCT GCG AA)-3'], HM3 [5'-(GGC CCA CTA TAT TAC ACC AAC CCC)-3] in accordance with Pirmez et al. (1999). The PCR-RFLP was undertaken in accordance with the protocol proposed by Volpini et al. (2004). By the PCR technique, the etiological agent was identified as Le. (Viannia) braziliensis.

\section{DISCUSSION}

In Mato Grosso do Sul (MS), human ACL has been attributed to Le. (Vi.) braziliensis and to Le. (Le.) amazonensis (Nunes et al., 1995; Dorval et al., 2006) and is considered a serious 
dermatological affection in the state, as a result of the growing number of cases, its presence in all the state's municipalities and the possibility of its occurrence in serious clinical forms.

Le. (Vi.) braziliensis has shown the ability to adapt to modified eco-systems and its transmission has been taking place in practically deforested rural areas and in peri-urban regions. The ecological changes which occurred in the settlement process have made possible the emergence of a domestic/peri-domestic transmission cycle, with the adaptation of the parasite to domestic animals, in particular to the dog, with simultaneous occurrence of the infection in human beings and these animals (Falqueto et al., 1991; Cunha et al., 2006).

In this same agricultural settlement from which the investigated dog came, in the late $90 \mathrm{~s}$, seven ACL cases were diagnosed among their residents and another in a Kadweo Indian village, an adjacent area. All the patients had the cutaneous form, with single or multiple ulcers and the parasite was identified as Le. (Vi.) braziliensis. Only adult males aged 19-48 years were affected by the infection. Five patients acquired the infection while working in areas undergoing deforestation in the neighborhood of the settlement and two while hunting early evening. As all the patients were adults working in forest or hunting in an area of savannah (Cerrado) and no cases were detected in women, children and domestic animals, it was concluded that the profile of the transmission of the parasite was related to occupational and leisure activities, resulting from the interaction of biological, ecological, economic, social and cultural determinants (Personal Communication, Nunes 1995, Uniderp).

Later, according to information provided by the Municipal Health Secretariat of Bonito, a woman and two teenage boys inhabiting the same house where the dog lived developed ACL. This fact suggests the establishment of an peri/intradomiciliary transmission cycle, where both humans and dogs can be infected by Leishmania (Vi.) braziliensis transmitted by sand flies, since in this same domicile two sand fly species, Lutzomyia longipalpis, which presents nocturnal biting activity and $L u$. almerioi, presenting nocturnal and diurnal biting activity have been identified with natural infection by Leishmania (Viannia) sp. (Galati et al., 2006; Savani et al., 2009).

Dog and man can enter incidentally in the Leishmania's transmission cycle. However, in some circumstances the dog may play a role of reservoir, as hypothesized by Falqueto et al. (1991), Cunha et al. (2006) and Pittner et al. (2009) in areas of occurrence of canine and human ACL. Although there is epidemiological evidence favoring this hypothesis, until now the role of the domestic dog in the Le. braziliensis transmission cycle has not been well elucidated.

Finding a dog infected with Le (Vi.). braziliensis together with evidences of human infection in woman and teenager in this agricultural settlement suggest that two different epidemiological profiles of transmission of this anthropozoonosis may be occurring: occupational and domiciliary.

Considering the spread of ACL through almost all the municipalities in MS, veterinary doctors should be attentive and prepared for the parasitological diagnosis of this affection in dogs, because the clinical manifestations of canine cutaneous leishmaniasis in these animals are non-specific and may be confused with other dermopathies such as auto-immune diseases or cutaneous neoplasms (Lascelles et al., 2000; Palumbo et al., 2010).

This is the first report of dog parasitism by Le. (Vi.) braziliensis in Mato Grosso do Sul (MS). The need for further studies on clinical, parasitological and immunological aspects of the progression of infection by Le. (Vi.) braziliensis in dogs should be emphasized as such studies could lead not only to the early diagnosis of canine cases, but also to the clarification of the role of this animal species in the epidemiology of ACL in this locality. 


\section{REFERENCES}

CUNHA， J.C.L.; LIMA，J.W.O; POMPEU, M.M.L. Transmissão domiciliar de leishmaniose tegumentar e associação entre leishmaniose humana e canina, durante uma epidemia na serra de Baturité, no estado do Ceará, Brasil. Rev. Bras. Epidemiol., v.9, p.425-35, 2006.

DORVAL, M.E.C.; OSHIRO, E.T.; CUPOLLILO, E. et al. Ocorrência de leishmaniose tegumentar americana no estado de Mato Grosso do Sul, associada à infecção por Leishmania (Leishmania) amazonensis. Rev. Soc. Bras. Med. Trop., v.39, p.43-46, 2006.

FALQUETO, A.; SESSA, P.A.; VAREJÃO, J.B.M. et al. Leishmaniasis due to Leishmania braziliensis in Espírito Santo state, Brazil: further evidence on the role of $\operatorname{dogs}$ as a reservoir of infection for humans. Mem. Inst. Oswaldo Cruz, v.86, p.499-500, 1991.

GALATI, E.A.B.; NUNES, V.L.B.; BOGGIANI, P.C. et al. Phlebotomines (Diptera: Psychodidae) in forested areas of the serra da Bodoquena, state of Mato Grosso do Sul, Brazil. Mem. Inst. Oswaldo Cruz, v.101, p.175-193, 2006.

LAINSON, R.; SHAW, J.J. New World leishmaniasis. In: COX, F.E.G.; KREIER, J.P.; WAKELIN, D. (Eds.). Topley \& Wilson's microbiology and microbial infections: parasitology. London: Hodder Arnold, 2005. Chapter 17. p.313-349.

LASCELLES, B.D.X.; PARRY, A.T.; STIDWORTHY, M.F. et al. Squamous cell carcinoma of the nasal planum in 17 dogs. Vet. Rec., v.147, p.473-476, 2000.
NUNES, V.L.B.; DORVAL, M.E.C.; OSHIRO, E.T. et al. Estudo epidemiológico sobre leishmaniose tegumentar (LT) no município de Corguinho, Mato Grosso do Sul: estudos na população humana. Rev. Soc. Bras. Med. Trop., v.28, p.185-193, 1995.

PALUMBO, M.I.P.; MACHADO, L.H.A.; CONTI, J.P. et al. Incidência das dermatopatias auto-imunes em cães e gatos e estudo retrospectivo de 40 casos de lúpus eritematoso discoide atendidos no serviço de dermatologia da Faculdade de Medicina Veterinária e Zootecnia da UNESP, Botucatu. Semina Ciênc. Agrárias, v.31, p.739-744, 2010.

PIRMEZ, C.; SILVA TRAJANO, V.; OLIVEIRA-NETO, M.P et al. Use of PCR in diagnosis of human american tegumentary leishmaniasis in Rio de Janeiro, Brazil. J. Clin. Microbiol., v.37, p.1819-1823, 1999.

PITTNER, E.; VOLTARELLI, E.; PERLES, T.F. et al. Ocorrência de leishmaniose tegumentar em cães de área endêmica no estado do Paraná. Arq. Bras. Med. Vet. Zootec., v.61, p.561-565, 2009.

SAVANI, E.S.M.M.; NUNES, V.L.B.; GALATI, E.A.B. et al. The finding of Lutzomyia almerioi and Lutzomyia longipalpis naturally infected by Leishmania spp in a cutaneous and canine visceral leishmaniases focus in serra da Bodoquena, Brazil. Vet. Parasitol., v.160, p.1824, 2009.

VOLPINI, A.C.; PASSOS, V.M.A.; OLIVEIRA, G.C.; ROMANHA, A.J. PCR-RFLP to identify Leishmania (Viannia) braziliensis and $L$. (Leishmania) amazonensis causing American cutaneous leishmaniasis. Acta Trop., v.90, p.31$37,2004$. 